by Dr. Mohendro Lal Sircar, a practitioner of medicine in the Irdian quarter of Calcutta.

At a time when Indian universities were the purely examining bodies so dear to the Philistine soul, when secondary education in India was mainly bookmongery (to call it "literary" would be a fault to heaven), and literary gentlemen were brought from England to feed raw Indian youths with husks of commentary laboriously ground from the English classics, Dr. Mohendro Lal Sircar, a medical man immersed in the anxieties of a private practice, was probably the only educated Indian in Ben'gal whose ideas of education were approximately those held generally to-day by men of science in Great Britain.

Dr. Sircar, being beyond his learning and accomplishments a man of great sagacity and urbanity, did not agitate or make a noise, but, with single-minded devotion to higher issues, he set a-going in a convenient part of his native town, and for many years carefully fostered, a society much of the style of the Companies of Friends of Natural History, the aim of which, to begin with, was, and had to be, generally educative. This society was appropriately called an association for the cultivation of science. By degrees, and by the accretion of laboratories for particular studies, the institution, while retaining an educational character, advanced to the differentiated technical stage; and now, beyond its educational purpose, it has become a well-organised and well-equipped institution for original experimental research.

The report for the year I9I4, lately received, shows that in addition to the seven regular courses of lectures on different branches of science delivered to students, there emanated from the association ten original papers-four on physico-mathematical subjects, five chemical, and one biological.

\section{NATIONAL RECONSTRUCTION.1}

THE British Science Guild, during the twelve years of its existence, has earnestly endeavoured to promote the public and official recognition of scientific research and of scientific organisation and methods as essential factors in national progress. Our journal and our annual reports show the matters to which we have striven to direct attention. It is not our object to secure the advancement of any particular branch of science; each has an association created for that purpose. We seek to provide what may be called a clearing-house of progressive thought, in order that activities which are mutually dependent may be harmonised for the welfare of the State and the Empire, and that the application of scientific knowledge not only to industries, but also to every department of public life, may become a reality. We believe that thus only can our future national advancement and the well-being of our people be placed upon a sound and an enduring foundation.

These are objects which in the past have powerfully appealed to men of science whose vision extended beyond the horizon of their labours to the conception of a State in which research was not only encouraged as a primary necessity of progress, but the results were quickly applied to the direction of energy, the prevention of waste, and the conservation of the forces on which the prosperity of mankind mainly depends.

Before the war, these were voices "crying in the wilderness." Governments and Parliament, which is supposed to control and inspire them, cared for none of these things. In our great public offices science was apt to be regarded as an abstruse mystery which

1 From the presidential address delivered at the annual meeting of th British Science Guild, held at the Mansion House, London, कn April $3 \circ$, by the Right Hon. Lord Sydenham, F.R.S possibly concerned business men and might sometimes obtrude itself inronveniently upon public attention, but had no part or lot in the administration. Speaking broadly, we have been ruled by men for whom scientific conceptions and scientific methods had little or no interest; and partly from this cause our industries were being stealthily undermined and were passing into the control of another people which had laboriously organised all its public and private activities, had been carefully trained quickly to turn scientific discoverieslargely borrowed-to material advantage, and had become obsessed with the mad ambition of imposing its theories of life and conduct by force upon the world.

The war has had the effect of turning a strong searchlight ufon the innermost workings of our national life. Our weakness and our potential strength stand plainly revealed. We can see how severely we have suffered and must still suffer from our neglect in the past; and if we strive to ascertain causes, we cannot fail to reach the conclusion that our lack of appreciation of all that science, using the term in the broadest sense, could have conferred upon us lies at the root of many present difficulties. When the question of con. traband was being considered, science could have told us what was vital to the prosecution of war by an enemy, and what, therefore, we should use every effort to exclude from his territories. Sir William Ramsay, whose loss, as one of our greatest leaders of scientific thought, we deplore, pointed out the gross fallacies which were permitted to mislead our policy in regard to cotton. Lard was assumed by one of our rulers to be innocuous, because he was unaware that its use for the manufacture of glycerine was an old discovery. The painful revelations of the Dardanelles Commission establish the facts that a fateful decision was arrived at by methods which flagrantly violated scientific prin. ciples, and that a complete misunderstanding as to some elementary artillery matters was allowed to exist. And now in the handling of the difficult question of man power there is an evident want of the grasp which sound scientific training can confer.

It would be easy to multiply instances of the ways in which the absence of scientific habits of thought have prejudiced the conduct of the war; but there is another side which must not be forgotten. If we have too often failed in foresight and in the application of orderly methods to the direction of policy, the national genius for improvisation has been strikingly manifested. On the basis of a small Army, the best we eve: possessed, we have built up, transported across the seas, equipped, and supplied vast national forces which have shown fighting power unrivalled in our military annals, and have determined the final victory of the cause of the Allies. And further, under the stress of war, we brought science to bear on military require ments in such a wav as not only to overtake, but to surpass, Germán appliances laboriously prepared in years of peace. On a different plane, the war savings propaganda is a good example of well-conceived and successful effort. Nothing can be more certain than that we possess organising capacity, which, if turned to full account, can perfectly respond to the future needs of the Empire.

Reconstruction is now beginning to occupy the minds of all thoughtful 'men and women. After-the-war problems are being widely discussed, and amid their baffing complexities some great principles stand out as signposts along the path which we must follow.

The material prosperity and the financial stability of the country can be restored only by an increase of pro. duction and interchange. This implies the creation of new industries anu the economic development of those which exist, combined with a firm hold on old markets

NO. 2479, VOL. 99] 
and the development of new ones. If our national resources were exhausted, we might well despair of the future; but the resources of the Einpire are almost inexhaustible, and their utilisation is only beginning. The Empire can produce all the great food staplesgrain, meat, sugar, and fats-sufficient for the supply of a far larger population than it now contains. The fish supply could be very largely increased from Ireland and the banks of Newfoundland. Raw materials of every kind, coal, and mineral oil abound. The Empire has almost a monopoly of some of the rarer metals and earths of which science is making more and more use. We have first to make certain that never again shall Germany obtain control of our raw materials and our key products, and then to ensure that our materials are, so far as possible, manufactured within the Empire. Before the war, almost the whole of the Imperial production of palm kernels went to Holland and Germany, and the oil expressed from them was exported to the United Kingdom as such, or in the form of margarine and other prepared fats. The story of the Australian zinc concentrates is well known. They and the output of Australian copper were discovered to be in German hands when war broke out, as was a great part of the manganese and hides of India. The re. sources of the Empire amply suffice for the rebuilding of our national prosperity, if by the unstinted application of science in the laboratory, in the workshop, and in the superior direction of commerce and industry they are turned to the fullest account.

The handling of the great question of the supply of power cannot be left to piecemeal treatment. We now have a Board of Fuel Research, which, in cooperation with the British Assciation, is investigating economics, and already an annual saving of fifty million tons of coal is known to be possible. Mr. Newlands estimates that in Scotland more than $x, 000,000$ electrical horse-power could be obtained from water, and he points out that, in Switzerland, one electrical horse-power obtained from water costs Il. Igs. per annum, as compared with $4 l$. I s $s$. $8 d$. in England from coal. The economic advantage of employing water power, wherever practicable, is manifest, and in parts of India, as elsewhere within the Empire, there are resources which need to be turned to account. In matters of such broad importance as power, lighting, and heat, research on the widest scale is necessary, and when conclusions have been reached their application can be secured by the active caoperation of the interests involved assisted by intelligent legislation.

In trade, the first requisite is sound information kept up to date, to which the Germans owe much of their success. We now have four Trade Commissioners representing the Dominions, and India must be similarly provided; but the whole system of consuls and commercial attachés in foreign countries requires complete reorganisation, which Government can carry out only by seeking and following the advice of experienced leaders of conmerce.

The Dominions Commission has shown the immense resources of the Empire, and in its final report it directs attention to the importance of cheap, speedy, and efficient transport between Imperial ports. Some years hgo I proposed the establishment of an "Imperial Maritime Council," composed of fifteen representatives of the various parts of the Empire, and financed by a $\mathrm{I}$ per cent, ad valorem surtax upon all foreign imports into Imperial ports, which in 1004 would have provided an annual income exceeding $4 \frac{1}{2}$ millions. The council was to deal with all matters relating to the maritime communicrations of the Empire, to build up inter-Imperial transport, and to ensure close study of the means of developing Imperial trade as a whole.
The Dominions Commission has now recommended the formation of an Imperial Development Board for these and other analogous purposes. This would be a great step in Imperial reconstruction, leading to farreaching results, provided that the board were exectitive, amply provided with funds, and completely severed from politics at home and overseas.

We have now a Department of Scientific and Industrial Research with a State endowment of one million, which will be able to exercise some of the functions of the Board of Science that the British Science Guild has strongly advocated. Each of the Dominions and India will require the same machinery, and $\mathrm{Mr}$. Hughes has undertaken that Australia shall be thus provided, while the Canadian Government has appointed an advisory council to advise a committee of the Cabinet on all matters relating to scientific and industrial research. We have also a Board of Scientific Studies which is carefully investigating our requirements. Systematic and co-ordinated research on a large scale is a primary need, and waste or duplication of effort can be prevented only by such general direction as to ensure that problems are attacked in the localities most favourable to their solution. Special attention must be given to chemistry, which has many important secrats to vieId. "The country," said Sir William Ramsay, "which is in advance in chemistry will also be foremost in wealth and general prosperity." We have certainly fallen behind Germany in this vitally important branch of science, not in the ability and insight of our chemists, but in numbers and in the application of chemical discoveries to industry. It is upon chemistry the use of power, and co-operative methods that agriculture must mainly depend for advancement.

National reconstruction will require in the future the sustained stimulus which education alone can supply. In our public schools and colleges science must take the place to which it has been long entitled. While trained specialists will always be relatively few. all who are destined to play a part in national affairs must receive such a grourding in the natural sciences as to ensure that physical laws and facts will appeal to them, and that scientific methods of thought will become habitual. For this reason, the British Science Guild has stronglv urged that a knowledge of science should be required of all candidates in examinations for the Civil Service. There need be no conflict with what are not well described as "humanistic studies." A broad general education is the best foundation for science training, and in so far as literary studies develop breadth of vision and clearness of style, they are valuable helps to the future specialist. Conversely such subjects as history take new form when they are approached in a scientific spirit.

A Parliament or a Government composed of specialists would be unsuited to its duties; but both need an intelligent appreciation of the relation of science to national life which is now consoicuously lacking. "Mankind," writes Prof. Dewey, of Columbra University, "so far has been ruled by things and by words. not by thought. . . . If ever we are to be governed by intelligence, not by things and by words science must have something to say about what we do and not merely about how we may do it more easily and economically,"

Avart from what we understand bv science teaching, there is the technical training which is needed by foremen and workers in industries, which should be such as to help the abler man to rise. The Departmental Committee on Tuvenile Education and Employment has recently renorted, and its main proposals are the retention at school of all children up to the age of fourteen, with attendance at continuation classes of 
at least eight hours a week up to eighteen. These classes are "to include general, practical, and technical education," and they will probably in many cases take the form of trade schools carrying on the education of young workers who have found employment. The advantages of manual training in primary schools are not sufficiently emphasised in the report. Manual dexterity can be acquired at an early age, and boys might thus gain a truer conception of the dignity of hand labour, while experience shows that technical or elementary scientific knowledge, if attained by practical work, becomes a permanent possession. Greater differentiation between the work of rural and of urban schools is another pressing need.

No one can maintain that our system of primary education has been a failure. As the President of the Board of Education pointed out the other day in his admirable speech, we owe to it, in part at least, the new armies which have brilliantly upheld our national honour on many stricken fields But we believe that education can do more in the future in developing moral stretıgth and in inculcating the sense of duty and good citizenship. Mr. Fisher has laid down as the ideal of his uffice that it should build the foundation "for a patriotic and social education worthy of the genius of our people, and a fitting monument to the great impulse which is animating the whole people in the war." We all hope he will be spared to realise that high ideal.

In the tremendous tasks which lie before the nation, Government can play an important part. Statesman. ship worthy of the name must lead, inspire, direct, and initiate. In guiding education, assigning defined functions to experts carefully selected for special purposes, exercising their-enormus patronage with a single eye to knowledge and efficiency, as well as in encouraging the progress of applied science, and guarding against legislation which mav hamper trade and industrial activity, there is ample scope for the action of Governments. Interference in the management of business enterprises will usually be harmful, since, for wellknown reasons, the conduct of business affairs by officials in democratic countries is rarely efficient.

Some tariff adjustments may be found desirable; but the idea that national prosperity can, in the long run, be ascured by ficcal devices is baseless. In so far as tariffs can stimulate the operation of natural laws, they mav be beneficial. When they aim at producing artificial conditions in defiance of law, they usually defeat their ends. Thev may be used legitimatelv, and we have been told that thev will be used to further the development of the resources of the Empire, and the object having been attained, they cæn be dispensed with.

I have onlv dealt with reconstruction in the material sense, which cannot alone guarantee the purer and happier national life which we all earnestly desire. That can be reached only if the whole nation will. in the difficult times that lie before it, follow the shining examples of duty, discinline, and self-sacrifice which have been set by our heroes on the seas, in the field. and in the air. The men who have constantly faced death and shared in dangers and hardshins will come back with a new outlook on life. In the trenches there have been no party divisions, no attempts to set class against class, but only shared efforts which are bringing certain victory to a sacred common cause. Mav we not hope that the great lessons learned by our best manhond in the storm and stress of war will react upon the nation as a whole and render the forms of politics to which we have orown accustomed impossible in the future? The strife of parties and of individuals contending for office and power, the intrigues which have not wholly ceased during this crisis in our fate, the machinery by which party cliests are filled and constituencies are manipulated, the false discipline which, by preventing men from voting according to their knowledge and conscience, vitiates the decisions of Parliament upon vital issues, the triunnph of words over experience and powers of action-all these things and more have had their day, and we begin to realise the inevitable $r \in$ sults.

Reconstruction in the highest and fullest sense can be achieved only by a great national party, seeking solely the welfare of the commonwealth, examining every public question from the view-point of the interests of the community as a whole, and choosing leaders irre. spective of class or party, who can be trusted to bring a lofty patriotism and trained intelligence to bear upon the vastly complex and far-reaching problems with which we are now confronted. If these are only visions, then I see no certain prospects of restoring the shaken fabric of the State, of rebuilding our prosperity on a broader and an enduring foundation, of healing the open wounds in our body politic, and of wresting lasting good from the gigantic evils of war.

\section{UNIVERSITY AND EDUCATIONAL INTELLIGFNCE.}

St. Andrews.-The Uniyersity museum has just received the entire collection of local and other birds, many very rare, made by Misses Baxter and Rintoul (of Largo and Lahill), for years known as authorities on ornithology, and joint editors of the Scottish Naturalist. They have, moreover, in interpolating these, gone over the entire University collection of birds and rearranged and labelled them. Accompanying this noteworthy and valuable gift, for most are exquisite examples of the taxidermist's art, are eight cases with drawers containing named collections of the eggs of birds and of Lepidoptera and other insects, as well as a few skulls and stuffed mammals.

Dr. P. MARIE has been appointed to succeed the late Prof. Dejerine as professor of clinical neurology in the University of Paris.

FräUlein A. M. Curtius, recently appointed lecturer in French by the philosophical faculty of Leipzig, is, according to the Nieure Courant, the first woman on the staff of a German university.

Tirnee research fellowships in, respectively, pathology and bacteriology, medicine, and surgery have been endowed in the University of Chicago by Dr. F. R. Logan, who has given a sum providing an income of $600 l$. a year for the purpose.

In his presidential address to the Institution of Mechanical Engineers on April 20, Mr. Michael Longridge considered the provision in this country of technical education for engineers. Many persons, he said, still fail to understand that the manual training which enabled an apprentice to become a master craftsman in times gone by does not suffice to turn a schoolboy into an engineer to-day. Differentiation is needed now in the training of the various classes of engineers and workmen, and it is this lack of differentiation which seems to be one cause of the inefficiency of our technical education relatively to its cost. The educa. tion available for the higher ranks of engineering is fairly satisfactory in Mr. Longridge's opinion, but that provided for the workman, both general and technical, is most unsatisfactory. "Yet the workman must have better education to qualify him to rise if capable, and to give those who have not the ability to rise some interests outside their dally work and football matches. and also to lessen drunkenness. The need will become 